\title{
Biodiversity governance and social-ecological system dynamics: transformation in the Australian Alps
}

\author{
Michael Lockwood $^{1}$, Michael Mitchell $^{1}$, Susan A. Moore ${ }^{2}$ and Sarah Clement $^{2}$
}

\begin{abstract}
Biodiversity conservation continues to be a challenging task for societies worldwide. We undertook a resilience assessment to address the following question: What are the ramifications of social-ecological system dynamics for biodiversity governance of a nationally significant landscape? Resilience assessment offers promise for guiding response strategies, potentially enabling consideration of ecological, social, economic, and governance influences on biodiversity-related activities. Most resilience assessments have, however, struggled to effectively incorporate governance influences. We applied a modified version of the Resilience Alliance workbook approach to explicitly address governance influences at each stage of an assessment of internationally significant biodiversity features in protected areas of the Australian Alps. The vulnerability of the Alps system to climate change suggests that it is moving into a release stage, with subsequent transformation hypothesized. Network governance is argued as enabling flexible, adaptive management and comprehensive engagement of stakeholders, both of which are critical to shaping how this transformation of the Alps as a valued focal system will occur. The Australian Alps Liaison Committee provides a promising governance structure for collaboration and comanagement across multiple jurisdictions. Our contribution was to demonstrate how a resilience assessment that explicitly embeds governance influences in social-ecological system dynamics can point to pathways for governance reform in the context of system transformation.
\end{abstract}

Key Words: adaptive cycle; biodiversity; climate change; governance; resilience assessment; transformation

\section{INTRODUCTION}

The magnitude of biodiversity loss around the world is well documented, with ongoing biodiversity decline largely attributed to human-induced impacts (Chapin et al. 2000, Millennium Ecosystem Assessment 2005, Butchart et al. 2010). A range of analytical, assessment, and planning tools and processes have been applied to address biodiversity conservation issues, including designation and reservation of networks of protected areas, increasingly based on systematic conservation planning; land-use planning, including management plans for protected areas; recovery planning for endangered species; and strategic and environmental impact assessments of development proposals (Geneletti and van Duren 2008, Genter et al. 2008, McGregor et al. 2011, Gregory et al. 2012, Gillson et al. 2013). These approaches have made little ground, however, in stemming biodiversity decline (Rands et al. 2010). The lack of success to date can be attributed to a constellation of factors. Most important and relevant to this discussion are the complexities of understanding, describing, and analyzing how biodiversity and its conservation interplay with society and governance.

Acknowledging and analyzing biodiversity as part of a socialecological system (SES) can greatly enhance our understanding of this interface with governance (Ostrom and Cox 2010). Such an integrated systems perspective enables concurrent consideration of the ecological, social, economic, and governance drivers and influences on biodiversity conservation and the interactions between them, and it facilitates subsequent analysis of how the system, including biodiversity, might then respond to policy interventions (Lebel et al. 2006, Lockwood et al. 2012, Haward et al. 2013). Resilience assessments have been promoted and used by researchers and practitioners to systematically and iteratively develop understandings of complex SESs (Resilience Alliance 2007a, b, 2010).

Recent critiques of resilience assessments have noted a largely functionalist approach to the "social" in SESs with little or no consideration of the influences of prevailing political circumstances or institutional structures (Hornborg 2009, Hatt 2013). Those undertaking such assessments have typically conceived the social in terms of locally expressed characteristics such as social capital, while paying little attention to social structures, including governance settings, which constrain, enable, and reproduce such characteristics (Hatt 2013). Institutions are the sets of rules, norms, and strategies that shape human interactions with each other and the environment; governance is the process by which these institutions are formed, applied, interpreted, and reformed (Hodgson 2006, Paavola 2007, McGinnis 2011). A governance regime is the complex of specific processes and associated institutions that are directed toward a focal issue (cf. Paavola et al. 2009).

Governance regimes offer potential points of intervention in an SES to enhance adaptation or pursue system transformation. Transformation may be actively chosen and implemented through institutional reforms designed to place the system on a trajectory toward a preferred basin of attraction relative to the current stability domain (Folke et al. 2010). Those facing an inevitable transformation might also seek to influence the process and outcomes of that transformation. Thus, governance interactions need to be considered alongside biophysical and socioeconomic drivers of change. Historic and contemporary governance regimes are implicated in biodiversity conservation crises, and so an approach of diagnosing and reforming governance 
arrangements is likely to offer new pathways to more desirable outcomes. This is why governance must be considered iteratively throughout the stages of a resilience assessment.

We address the following question: What are the ramifications of SES dynamics for biodiversity governance of a nationally significant landscape? To answer this question, we used a modification of current resilience assessment approaches that explicitly included governance in all stages of the assessment.

Our assessment is focused at a "landscape" scale, with the focal system being the 160,000 ha alpine and subalpine treeless region of the Australian Alps that supports internationally and nationally significant biodiversity features (McDougall and Walsh 2007). Most of this system is managed as national parks. The landscape is highly susceptible to a drying, warming climate (Hennessy et al. 2008), and its features and functions will struggle to survive within a climate space that is predicted to no longer exist by 2100 (Williams et al. 2007). The effects are expected to be most acutely evident in communities such as wetlands and snow patch vegetation that are dependent on current temperature and precipitation regimes (Pickering et al. 2004, McDougall and Walsh 2007), and in ski resorts that may face closure because of lack of snow (Pickering 2011).

\section{METHODS}

Workbooks produced by the Resilience Alliance (2007a, b, 2010) provide a series of iterative steps for assessing sustainability from a systems perspective. Earlier versions placed less emphasis on governance as an intervention strategy, referring instead to institutional interventions and the benefits of adaptive governance in building adaptability and transformability. In the revised 2010 practitioners' version, governance aspects are identified as critical to understanding system dynamics and development of management interventions. In the modified assessment approach we provide subsequently, we take this trend further by incorporating governance as integral to all stages of the assessment.

Our approach draws on these workbooks and Strickland-Munro et al. (2010) to define four stages for our analysis, crafted to provide a particular focus on the place and role of governance in SESs. Defining the focal system (Stage 1) was an essential starting point, a task that was undertaken in close discussion with key stakeholders. Identifying a focal scale and issue can help to ensure that the next stage of identifying drivers is not excessively broad. Governance features of the SES were a key consideration in the first stage and provided the context for the remainder of the analysis.

Factors affecting the system (Stage 2), and specifically drivers of change, identify and help explain what has shaped the current system and might be influential in the future (Resilience Alliance 2010). We describe the key drivers of change for biodiversity in the focal system and their interactions with the governance regime. We first reviewed the historical and contemporary evidence, encompassing more than 150 articles, regarding the trajectory of the focal biodiversity features and associated biophysical and social drivers, and documented current governance and management arrangements. Drafts of this review were amended in response to comments from several key informants, including 6 scientists with substantial research and managerial experience in the Australian Alps.
An assessment of the relative importance of drivers and governance and management influences, and development of a conceptual SES model indicating relationships between important drivers, governance and management influences, and biodiversity features, was undertaken by the research team in collaboration with scientists and representatives from key organizations associated with biodiversity management in the focal landscape. The main vehicle for this collaboration was a 2day workshop attended by 32 participants: 10 parks agency staff from Victoria, 2 from New South Wales (NSW), and 1 from the Australian Capital Territory (ACT); 3 from the Australian government environmental agency; 1 from the Victorian state environmental agency and 3 from local governments in the region; 3 alpine resort managers; 1 Australian Alps Traditional Owners representative; 6 scientists; and 2 knowledge brokers. These participants were identified with the support of a knowledge broker who also worked for the Australian Alps Liaison Committee, an umbrella organization created by the 4 agencies responsible for managing Australian Alps national parks to promote greater interagency coordination.

Workshop participants were sent the review of historical and contemporary evidence prior to the workshop to help in their preparations. At the workshop, we first explained that the aim was to establish a broad understanding of the system, i.e., to minimize complexity while not leaving out anything of importance. We presented lists of social and biophysical drivers and governance influences identified from the literature review, and we invited modification and additions. Participants then rated each driver/influence in terms of its importance, directly or indirectly, for shaping biodiversity outcomes from 2013 to 2030. Drivers were rated on a 5-point scale from "No Importance" to "Very High Importance." Governance and management influences were rated on a 5-point scale from "No Influence" to "Very High Influence."

The distinction in terminology between "influences" and "drivers" is to indicate that drivers operate exogenously to the governance regime but can be influenced by it. That is, the governance regime modifies the action of social and biophysical drivers on the focal features of interest. As we show subsequently, our case study regime influences social drivers, as well as having a limited influence on the actions and consequences of fire and water in the landscape. However, the most important driver, climate change, is beyond the influence of the biodiversity governance regime for the Australian Alps.

Stage 3 addressed system dynamics, and we focused on our application of the widely used adaptive cycle heuristic to the longer term system dynamics of the Australian Alps. The fourphase adaptive cycle provides an accessible means for illustrating the dynamics of change and stability in SESs (Holling and Gunderson 2002).

Stage 4 explored the implications for interventions given the current and past structure and function of the focal system. In our case, the likely/possible trajectories, based on the hypothesized adaptive cycle for the Alps focal system, and the extent to which changes in governance can influence the likely trajectories, informed this exploration. We also adopted the approach suggested by Folke et al. (2010) of identifying intervention strategies that are framed around the likelihood and desirability of the system persisting in its current form, adapting 
to remain within the same basin of attraction, or transforming to another system state.

The sources of information varied with the stage. For Stage 1, the focal region, issue, and scale were determined in close consultation with park managers. The governance features detailed in this stage came from document reviews. The drivers in Stage 2 came from a review of the literature and detailed consideration and analyses by workshop participants. The adaptive cycle analysis of Stage 3 and the implications for interventions from Stage 4 were developed by the authors.

\section{Case study choice}

This assessment focuses on biodiversity conservation at the "landscape" scale, with the focal system being the treeless region of the Australian Alps. The selection of the Alps region was driven by Australian government's interest in exploring challenges associated with landscape-scale conservation of nationally significant biodiversity features. In the Alps, this significance rests on 710 native plant species recorded, with $30 \%$ of these restricted to treeless vegetation in the Australia Alps and a further 14\% restricted to treeless vegetation in general (McDougall and Walsh 2007). Impacts of climate change on local endemic species distribution make the Australian Alps particularly vulnerable because there is no scope for upward mobility of affected species. Through consultation with parks agency staff, we expanded our initial focus on alpine and subalpine wetlands to the surrounding treeless plains and, eventually, to include adjacent snow gum (Eucalyptus pauciflora) woodlands, reflecting the fluid boundaries of such a mosaic landscape. The region is also socially and economically important for its tourism and recreation opportunities as the only snow sports destination in mainland Australia.

From a governance perspective, almost the entire focal system is designated as protected areas, predominantly national parks (Fig. 1 ), and managed by state and territory conservation agencies. These protected areas have been formally established under three different legislative regimes in the states of NSW and Victoria, and the ACT. Although each of these regimes ensures that biodiversity conservation is an important focus for management, they vary in the configurations of the governing authorities and the mechanisms to address use and development within the parks. As discussed subsequently, the focal system also includes a number of alpine resorts.

Because protected areas are a key mechanism for conserving biodiversity, as emphasized, for example, in the strategic plan for the Convention on Biological Diversity (SCBD 2010), it is of interest to analyze whether the conservation-focused governance of the case study landscape is well placed to conserve extant biodiversity. Selection of a large region for attention was deliberate, given recent emphases by the Australian government on assessing, planning, and managing for biodiversity at a landscape scale rather than focusing on individual species (Hawke 2009) and on large-scale connectivity conservation initiatives (Wyborn 2011). These emphases are based on the premise that working at a landscape scale is more effective in achieving biodiversity conservation outcomes by enabling systematic and comprehensive analysis of issues such as fire, feral animals, and weeds (Wyborn 2011), as well as better identification of key points and means of intervention (Worboys et al. 2010, Wyborn and Bixler 2013).
Fig. 1. Major protected areas in the Australian Alps.

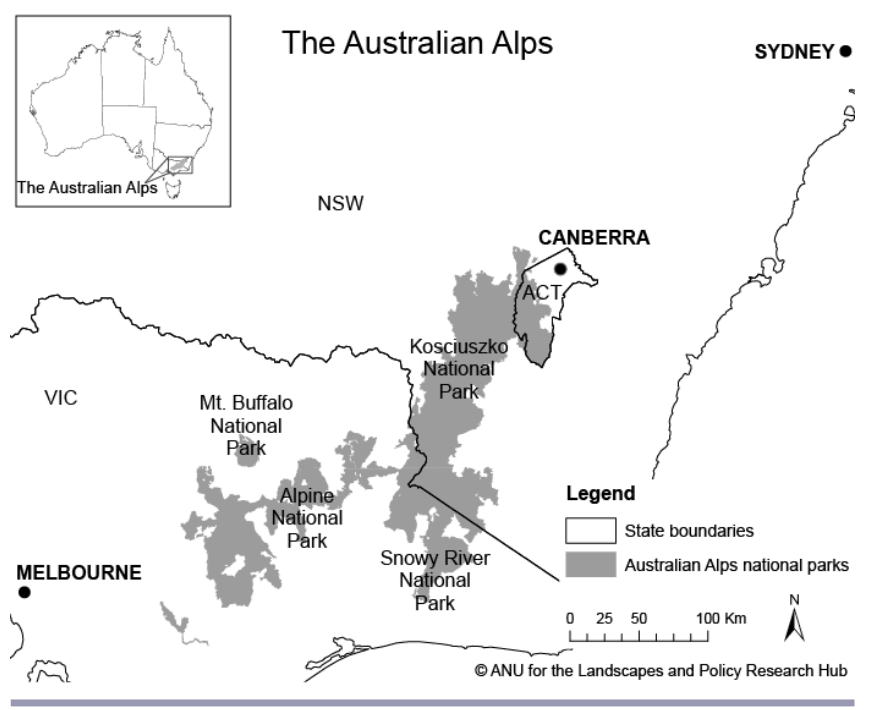

\section{RESULTS}

Stage 1: the focal system

The focal system includes the alpine and subalpine areas of the Australian Alps, comprising a mosaic of grassland, heathland, wetland, and woodland, together with associated threatened fauna, such as the mountain pygmy-possum (Burramys parvus), threatened flora, and ecological communities. Our rationale for choosing this system was explained previously, and its features and values are summarized in Table 1.

The governance of this focal system is dominated by the national park as an institution, managed by state and territory governments according to legislation specific to those jurisdictions, as well as international, national, state, and parklevel policies and plans (Table 2). Cross-border management and research activities are coordinated by the Australian Alps Liaison Committee. The associated Cooperative Management Program operates under a Memorandum of Understanding (MOU) signed by the Australian, NSW, Victoria, and ACT governments in 1986 and current today. This program aims to manage the Alps as one biogeographic region through fostering cooperation on water and catchments, fire management, Aboriginal heritage and engagement, and invasive animal control. The MOU has proved strong and flexible enough to survive political and funding cycles, major fire events, and contentious management issues like grazing in Victoria and most recently wild horse management (Crabb and Dovers 2007).

Although the focal landscape has in some ways a simpler governance setup than say a multitenure agricultural landscape with a diversity of individual landholders, the regime is nonetheless subject to a variety of pressures that both support and challenge the achievement of biodiversity outcomes. As publicly owned, governed, and managed national parks, the rules and broad objectives for biodiversity management in the focal system are specified in legislation and associated regulations. Specific management decisions are guided by management plans 
Table 1. Biodiversity features of the Alps focal system.

\begin{tabular}{lll}
\hline \hline Zone & Alpine & Subalpine treeless areas $\dagger$ \\
\hline Area and elevation & $\begin{array}{l}25,000 \text { ha } \\
\text { Above 1800-1850 meters above sea level (asl) in NSW and } \\
\text { above 1600-1750 meters asl further to the south in }\end{array}$ & $\begin{array}{l}135,000 \text { ha } \\
\text { Between 1450-1850 metres asl in NSW and ACT, and } \\
1300-1750 \text { metres asl in Victoria. }\end{array}$ \\
& $\begin{array}{l}\text { Victoria }+ \text { - highest points are in NSW: Mt Kosciuszko (2228 } \\
\text { metres), and in Victoria: Mt Bogong (1986 metres). }\end{array}$ & \\
Main vegetation & $\begin{array}{l}\text { Mosaic of grassland, heathland, and wetland vegetation } \\
\text { types }\end{array}$ & $\begin{array}{l}\text { Mosaic of grassland, heathland, wetland, and boulder heath, } \\
\text { distributed within a matrix of snow gum (Eucalyptus } \\
\text { Features recognized }\end{array}$ \\
& $\begin{array}{l}\text { boulder heath, and low alpine herbfield. } \\
\text { Ramsar listed wetlands: Blue Lake and Hedley Tarn (alpine) and Ginini Flats subalpine bog complex (subalpine). }\end{array}$
\end{tabular}

under state, national, and international laws and conventions.

Environment Protection and Biodiversity Conservation Act 1999 (Cth; EPBC Act) listed ecological community: Sphagnum Bogs and Associated Fens Ecological Community (alpine and subalpine).

EPBC Act listed species: 6 fauna species, including the endangered mountain pygmy-possum (Burramys parvus; alpine and subalpine), critically endangered southern corroboree frog (Pseudophryne corroboree), and northern corroboree frog (Pseudophryne pengillyi; both subalpine only), and 14 flora species, such as the critically endangered Bago leek-orchid (Prasophyllum bagoense) (subalpine) and the vulnerable anemone buttercup (Ranunculus anemoneus; recovered from near extinction and only surviving in alpine zone).

In addition: 17 flora species are listed on the IUCN's red list (McDougall and Walsh 2007) and many more species are listed under separate NSW, Victorian, and ACT threatened species legislation, such as the broad-toothed rat (Mastacomys fuscus), listed as vulnerable under NSW legislation.

$\uparrow$ Although below the climatic tree line, diurnal temperature inversions produce extremely low temperatures in cold air drainage basins, preventing the establishment of trees in these subalpine areas (Williams and Ashton 1987).

$\$$ The altitude of the tree line, which marks the lower boundary of the alpine zone, varies depending on latitude and local microclimate.

prepared in accordance with this legislation. However, these prescriptions can be subject to a range of interpretations, and decisions are typically influenced by new scientific information postdating management plans, as well as governance authorities' consideration of stakeholder preferences and associated political pressures. Influential stakeholders are indicated in Table 2. Crossscale influences through international and national agreements and legislation (Table 2) are also important.

Both Parks Victoria and the NSW National Parks and Wildlife Service have coordinated efforts within their own state boundaries, over the past decade, to collect information on how their park and reserve system is performing (Jacobson et al. 2008). Three iterations of "state of the park" reporting have been undertaken in both states, with such an approach identified as part of adaptive management (Hockings et al. 2009). Consideration of resilience in the iconic Kruger National Park places adaptive management center stage (Du Toit et al. 2003, Venter et al. 2008). The alpine national parks have been included in these state of the park analyses. Growcock et al. (2009) note that iterative testing against departmental plans and legislative objectives has been possible via this reporting. The managing agencies are making ongoing efforts to institutionalize learning from these assessments.

The Australian Alps have been used by Aboriginal people at least since 4500 BC (Flood 1992, Kamminga 1992). Major activities in the high country centered on annual gatherings and ceremonial activities, some associated with feasting on Bogong moths (Agrostic infusa) that migrate annually to the Alps (Flood 1992).
Aboriginal people still have a connection to the Alps region and are engaged in management of the alpine national parks through the Australian Alps Traditional Owners Reference Group.

\section{Stage 2: factors affecting the system}

The drivers of change in this focal system are a complex of biophysical, socioeconomic, and governance elements. Our review of historical and contemporary evidence described more than 30 such drivers, around half of which are related to governance influences. We have included the 6 drivers that were rated as being of high to very high importance by stakeholders in the workshop and examine governance interactions with these drivers.

\section{Climate change}

Climate change is already affecting the Australian Alps, as evidenced through a $30 \%$ reduction in snow cover (Pickering 2011). Because the distribution of flora and fauna is in part determined by snow presence, depth, and persistence, such changes are expected to have substantial impacts on alpine biodiversity (Pickering and Armstrong 2000, McDougall and Walsh 2007). Average temperatures are predicted to increase by $2.9^{\circ} \mathrm{C}$ by 2050 , and rainfall to decrease by $24 \%$ over the same period (Hennessy et al. 2008). More frequent and severe droughts are also predicted (Macdonald 2009).

This combination of influences, originating outside the focal system, makes climate a key driver of change. The lowtemperature conditions that have created the structure, species mix, and dynamics of the focal system's alpine and subalpine 
Table 2. Governance features of the Alps focal region. ${ }^{\dagger}$

\begin{tabular}{ll}
\hline \hline International & National/Trans-state \\
\hline Administrative responsibility: & \\
Ramsar Conference of the & Department of \\
Contracting Parties - policy & Sustainability, Environment, \\
& Water, Population and \\
& Communities (SEWPaC) - \\
& administers matters of \\
& national environmental \\
& significance (MNES), which \\
& applies to listed species and \\
& communities, listed National \\
& Heritage, Ramsar sites
\end{tabular}

Ramsar Standing Committee and Secretariat - implementation Convention on Biological Diversity (CBD) Conference of the Parties - governing body Secretariat of the CBD administrative support

Conventions and legislation: Conventions:

Ramsar Convention on Wetlands of International Importance

Convention on Biological Diversity (CBD)

Key strategies and plans: CBD Strategic Plan for Biodiversity 2011-2020 (includes Aichi Biodiversity Targets)

Formalized advisory functions: Ramsar Scientific and Technical Review Panel

CBD Subsidiary Body on Scientific, Technical and Technological Advice
State/Territory

NSW National Parks and Wildlife Service, a division of Office of Environment and Heritage within the Department of Premier and Cabinet (NSW) - park policy and management

Department of Environment and Primary Industries (DEPI; Victoria) - park policy

Parks Victoria (Victoria) - park management

Alpine Resorts Coordinating Council (Victoria) - strategy and research

Alpine resort management boards (Victoria) - resort planning and management Parks and City Services Division of Territory and Municipal Services (ACT) park policy and management

Administering legislation: Environmental Protection and Biodiversity Conservation Act 1999 (Cth) - identification of MNES and establishment of associated impact assessment procedures

Administering legislation:

National Parks and Wildlife Act 1974 (NSW) - designation and management of protected areas

Threatened Species Conservation Act 1995 (NSW) - listing of threatened species and associated conservation and recovery processes

National Parks Act 1975 (Vic) - designation and management of protected areas

Crown Land (Reserves) Act 1978 (Vic) - designation of alpine resorts Alpine Resort Management Act 1997 (Vic) - establishment of resort management boards and a coordinating council

Flora and Fauna Guarantee Act 1988 (Vic) - listing of threatened species and associated conservation and recovery processes

Nature Conservation Act 1980 (ACT) - species protection and management of conservation reserves

National Reserve System Strategy 2009-2030

Australia's Biodiversity Conservation Strategy 2010-2030

National Wildlife Corridors Plan 2012

Australian Alps Program

Strategic Plan 2011-2014

Australian Alps Liaison

Committee -

intergovernmental

cooperation
Kosciuszko National Park Plan of Management 2006 (NSW)

Greater Alpine National Parks Management Plan (under preparation, as of July 2013; Victoria)

Namadgi National Park Plan of Management 2010 (ACT)

Alpine Advisory Committee - provides advice on management plans to the Environment Minister (Victoria) 


\begin{abstract}
Key stakeholders:
IUCN World Commission on

Protected Areas
\end{abstract}

International visitors
Conservation NGOs (e.g., Australian Conservation Foundation, Victorian National Parks Association)

Tourism bodies (e.g., Tourism Traditional Owners Northeast [Victoria], Snowy

Regional Tourism [NSW])

National and state visitors Club)
User group organizations (e.g., Mountain Cattleman's Association, Victorian Deer Association, Snowy Mountains Bush Users Group [NSW], Victorian Brumby Association, Bogong Horseback Adventures, Border Bushwalking

Local governments (e.g., Alpine Shire Council [Victoria], Snowy River Shire Council [NSW])

Local visitors

${ }^{\dagger}$ Correct as of July 2013. Many of the organizations and instruments in this table have functions additional to those indicated.

ecosystems make them highly sensitive to climate change (Spehn et al. 2002). Under a warming climate, alpine ecosystems in particular lack any higher ground to move into and will be under pressure from species currently restricted to lower elevations (Pickering et al. 2004). Snow gum woodlands, for example, are likely to expand into areas that are currently occupied by grassland and heathland vegetation (McDougall 2003, McDougall and Walsh 2007).

The effects of climate change will differentially affect components of the alpine and subalpine vegetation mosaic. Alpine and subalpine wetlands are likely to be impacted through more extended periods of drought, increased average and peak temperatures, increased incidence of wildfire, and impacts from new and extant invasive species (Macdonald 2009). Even a small increase in mean ambient temperature is likely to result in the loss of wetlands because of changes in snowfall and snowmelt regimes (Pickering et al. 2004). Heathlands are expected to be resilient to climate change over the next 20 to 30 years with recent experimental work in the Bogong High Plains suggesting that changes in diversity and cover changes will be small rather than transformational (Wahren et al. 2013). Pickering and Armstrong (2000) suggest that heath communities are likely to increase in area as increasing temperatures and declining snow cover favor shrub species over grasses and herbs.

Reduced snow cover is expected to have a detrimental effect on alpine fauna. The mountain pygmy-possum, for example, is likely to suffer a contraction in suitable habitat, increased winter mortality, and more competition from low-altitude species (Pickering et al. 2004). Climate change may also affect the breeding success of alpine frog species in ephemeral pools because the pools have the potential to dry before the tadpoles reach metamorphosis (Hunter et al. 2009).

Climate change, and the associated reduction in snow cover, is also likely to affect the ski industry and water production. Under high-emission scenarios, the duration of the ski season based on natural snow cover is projected to decline. Across the Victorian ski resorts of Falls Creek and Mt. Hotham, for example, the average snow season is forecast to become 5-35 days shorter by 2020, and 20-80 days shorter by 2050 (Bhend et al. 2012). Continuation of the industry will require a significant expansion of artificial snowmaking, which is only likely to be viable in the higher altitude resorts (Pickering et al. 2004, Hennessy et al. 2008). The observed dramatic reduction in winter visitation during poor snow seasons is indicative of the challenges facing Australian alpine resorts (Pickering et al. 2004). Although investment in snowmaking is helping to address these challenges, the resorts are under pressure to identify strategies to develop and market their less economically lucrative summer events and activities (ARCC 2012).

Invasive processes

Compared with other Australian bioregions, alpine areas have hitherto only been lightly impacted by introduced plant species because of generally unfavorable climatic conditions and restricted dispersal (McDougall et al. 2005). Nonetheless, 131 nonnative plant taxa have been recorded in alpine and subalpine areas of the Australian Alps (McDougall and Walsh 2007), and the recent expansion of orange hawkweed (Hieracium aurantiacum) into the Australian Alps is of major concern (Williams and Holland 2007). Amenity plantings in ski resorts are emerging as a major source of new invasive species (McDougall et al. 2005, Pickering and Hill 2007), and more frequent fire events in the Australian Alps are also driving invasive processes. Following the 2003 fires, subalpine wetlands in Victoria that were largely weed free were invaded by a number of exotic species (McDougall and Walsh 2007), including the willow species Salix cinerea, which without active eradication efforts could permanently affect floristic composition and structural integrity (McDougall 2007).

Climate change is expected to increase the susceptibility of alpine and subalpine areas to invasive processes because increased temperatures and reduced snowfall create conditions that enable species currently restricted to lower elevations to move upslope (Green and Pickering 2002, McDougall and Walsh 2007). Reduction in snow cover has been implicated in increased predation of native species such as the broad-toothed rat (Mastacomys fuscus) by the introduced red fox (Vulpes vulpes) (Green and Sanecki 2006), and such pressures are likely to intensify. Domestic cattle (Bos taurus) and horses (Equus caballus) have been deliberately introduced into the Australian Alps. Given the lasting legacy of biodiversity impacts from the former, and the ongoing impacts from horses now gone feral, both these species are important to our consideration of invasive processes.

Cattle grazing in the Australian Alps commenced in the 1830s in the NSW Kosciuszko region and in the 1850 s on the Victorian Bogong High Plains (Kamminga 1992, Wahren et al. 1994), and 
its effects have been well documented. Alpine and subalpine wetlands have been reduced to less than half of their preEuropean extent (Good 2006), with only 30\% of this remaining area having intact hydrologic function (Pickering et al. 2004). Trampling by stock compresses the moss in bogs and fens, leading to drying and increased erosion following heavy rainfall, snowmelt, or burning (Wimbush and Costin 1983, Hope et al. 2009). Grazing has also caused a progressive thinning of grassland in the Kosciuszko alpine area and its ultimate conversion into to an erosion feldmark (Good 2006), and it has shifted other grassland areas to heathland on both the Bogong High Plains (Williams and Ashton 1987, McDougall 2003) and in Kosciuszko National Park (McDougall and Walsh 2007). Considerable restorative action has been undertaken in the Kosciuszko alpine area since the 1960 s.

Regulation of use, attempted from the 1840s onward in NSW and 1920s in Victoria, was undertaken on a state rather than national basis, given that in Australia responsibility for land management resides almost exclusively with state governments. Separate but, on occasions, related management of the Alps focal region characterizes its history and is an abiding institutional influence on its management. Evidence of the effects of alpine grazing and the commencement of the Snowy Mountains Hydroelectric Scheme, which was dependent on high-quality water from the mountains, prompted the NSW government to progressively remove grazing from these areas. A complete phase out of grazing from Kosciusko National Park in NSW was achieved in 1969 (Good 1992). Pressure from scientists and conservation nongovernmental organizations (NGOs) led to a similar sequence of events in the Victorian high country, but grazing was not completely removed from the Victorian Alps until 2005. In 2010, a conservative Victorian government overturned the 2005 Labor government decision and commenced a trial of the contribution cattle make to reducing fire risk. The scientific credibility of this trial was widely questioned (Garrard and Rumpff 2011), and the published evidence suggests that cattle grazing in the Alps has no significant effect on fire risk (Williams et al. 2006). The Australian government intervened, on the basis of the National Heritage listing of the Alps (Table 2), removing cattle again the following year. In 2013, the move was challenged in court but upheld (Federal Court of Australia 2013).

A major contemporary issue facing parks managers across the Australian Alps is a rapid increase in the number of wild horses (Dawson 2009), with limited socially acceptable means for reducing the population. Horses were introduced into the Australian Alps by early graziers, and wild populations soon became established. Though currently found in relatively low numbers at higher altitudes (Pickering et al. 2004), this may change as snow cover declines. The damage caused by horses to alpine and subalpine wetlands is similar to that caused by cattle and includes changes in vegetation composition, erosion, and channeling of peat wetlands (Hunter et al. 2009). The ACT, NSW, and Victorian park management agencies have prepared control strategies and are implementing associated programs. Feral horses have also been listed as a threatening process under Victorian legislation. Their management is contested, however, with the Snowy Mountain "brumbies," an affectionate and colloquial term used for feral horses, having an important place in history and literature for many Australians.
Fire

Fire is a driver of the biodiversity of the focal system through its potential to change the structure and function of the vegetation. How this occurs depends very much on fire frequency and intensity. Its behavior increasingly depends on the changing climate where weather extremes and increasing temperatures seem linked to more frequent, more intense fires (Bowman et al. 2011).

Pre-European settlement, high-intensity fire in high subalpine and alpine vegetation occurred approximately once per century, when periods of extended regional drought coincided with extreme fire weather and multiple ignition points (Zylstra 2006). Fire frequency in many areas of the high country increased significantly following European occupation, first through the actions of graziers and also through an increased incidence of major wildfires encroaching into the high country from lower elevations. For example, large fires affected the alpine and subalpine areas of Kosciuszko National Park in 1939, 1964-1965, 1984-1985, and 2003. The 2003 fire burned more than 10,000 ha of the treeless alpine and subalpine vegetation. Parts of the Bogong High Plains were burned in 2003 and again during the 2006-2007 fire event, affecting a local population of mountain pygmy-possums (Williams et al. 2008), and other areas burned in 2003 were burned again in 2013.

Research into the response of alpine and subalpine vegetation to the 2003 fires suggests that some components of these environments are resilient to infrequent and intense landscapescale fire events (Williams et al. 2008). Eight years after the 2003 fires, heathlands on the Bogong High Plains were approaching a similar species composition and abundance to that evident before 2003 (Camac et al. 2013). In the absence of further fire events, it is expected that most grassland and heathland communities will return to their prefire species composition (Wahren et al. 1994, Walsh and McDougall 2004). However, despite the general resilience of these vegetation types, repeated fire events will have potentially deleterious impacts on some alpine vegetation communities such as wetlands, with large burned patches perhaps taking decades to recover or not recovering at all if there has been a consequent major disruption to local hydrology (Walsh and McDougall 2004, Williams et al. 2008).

On 7 February 2009, bushfires in Victoria burned approximately 430,000 hectares and killed 173 people. Reactions to this fire, following closely on other major fires in 2003 and 2006-2007, pressured governments to strengthen measures to reduce fire risk. The Victorian government's Royal Commission into the 2009 fire endorsed calls for a hazard reduction burning target of $5 \%$ of all public lands per annum, which subsequently became state policy. A similar policy exists in NSW, despite evidence that it would not significantly reduce the risk to assets (Gibbons et al. 2012). Because hazard reduction burning is not undertaken in the alpine and subalpine treeless landscapes, and given that prevention and mitigation methods in the adjacent forested areas have limited capacity to deal with major fires, such policies are likely to have little direct effect on the frequency and intensity of future fire events in the alps. Research also suggests that there is no conservation imperative for active fuel reduction strategies (Camac et al. 2013). Such a conclusion, however, is not politically palatable, and some regional landowners and graziers, for example, have pressed claims for stronger interventions, 
including, as noted previously, the reintroduction of grazing. In this politically charged environment, establishing a science-based approach to fire management is difficult.

\section{Tourism and recreation}

The Australian Alps have attracted tourists and recreationists for more than 150 years. Winter activities are primarily alpine and cross-country skiing, with activities in other seasons including bushwalking, camping, horse riding, four-wheel drive touring, fishing, deer hunting, canoeing, rock climbing, caving, and sightseeing. The associated visitors provide economic and employment benefits to the tourism industry and regional communities, especially during the winter ski season, while at the same time contributing to environmental impacts, especially during the summer season.

There are 8 resort areas in the Australian Alps with 2924 ha suitable for alpine skiing, which in 2011 attracted about 2.5 million ski visitor days (Morrison and Pickering 2012). Ski tourism is one of the principal economic activities in the Australian Alps (Pickering et al. 2004). In the 2011 winter, the Victorian alpine resorts contributed an estimated $\mathrm{A} \$ 610$ million to their state economy and supported 6200 equivalent full-time jobs. Over the same period, the NSW alpine resorts contributed an estimated A $\$ 1054$ million to their state economy and supported 10,500 equivalent full-time jobs (NIEIR 2012).

Resort governance differs in the two states. NSW ski resorts are within the Kosciuszko National Park and are run by private organizations under leasehold arrangements authorized by the NSW minister for the environment under the National Parks and Wildlife Act 1974 (NSW). In Victoria, the resorts are established under the Crown Land (Reserves) Act 1978 (Victoria), and those in the focal region are surrounded by national park. Each resort has a management board with oversight and promotion provided by the Alpine Resorts Coordinating Council. The boards and council are established under the Alpine Resort Management Act 1997 (Victoria).

To better manage their environmental impact, the Alpine resorts are implementing environmental management systems. All four NSW resorts have such systems in place, and most of the resort management boards in Victoria have environmental management plans and employ environmental management officers to implement them.

\section{Community values and attitudes}

How parks and their accompanying biodiversity values are perceived by the Australian and international communities, and the associated attitudes of communities toward management direction and strategies, affects the decisions made by governance authorities and the levels of funding available to those authorities (Weiler et al. 2013). As such, community values and attitudes are a critical driver for the Alps focal system. General trends of values and attitudes relevant to the Alps can be gleaned from survey research with the broader Australian population.

Surveys of Australians undertaken in 2007 and 2011 rated environmental sustainability, which included climate change and biodiversity loss, as the third highest concern in 2007, but this issue had decreased in relative importance by 2011 (Devinney et al. 2012). This said, a recent survey reports that $3 / 4$ of Australians enjoyed the benefits of the natural environment, with some contact with nature over the past 12 months (ABS 2013). The most popular activity was visiting a national park or botanic garden (ABS 2013). NSW and Victorian voters, as reported by Winter and Lockwood (2004), appreciated nature for its nonuse values, i.e., the satisfaction of knowing natural areas exist in good condition; then for its intrinsic values, i.e., the value of nature for its own sake; and finally, and least so, for its use values, such as resource production and recreation.

Although no social research has been undertaken on the values and attitudes toward the Australian Alps, the authors' experiences as longtime contributors to and observers of land-use decisionmaking and planning processes in the focal region, and in particular Land Conservation Council investigations into the Alpine Study Area in the 1970s, and the Victorian Alpine National Park Management Plan in the early 1990s, indicate that many people have deeply held intrinsic values for the Alps, while userelated values are also significant. These values coalesce into very different ideas about the purpose and uses of national parks. Views at one end of the spectrum disfavor all uses of national parks except for low-impact recreation, whereas those at the other end oppose protected areas and advocate for cattle grazing, timber harvesting, hunting, and four-wheel driving throughout the mountains. Moderate views include support for national parks with some uses supported such as motorized and resort-based tourism and recreation. The present NSW and Victorian governments are adopting strong pro-use policy platforms that include increasing opportunities for users such as hunters and four-wheel drive enthusiasts and supporting the further development of resorts within the Alps protected areas.

\section{Hydroelectricity and water production}

Hydroelectricity schemes operate within the Alps focal system in both states, and the focal system provides a reliable flow of water for nationally important irrigation schemes. Associated extensive infrastructure development includes hydroelectric power stations, aqueducts, pipelines, and access roads. The hydro schemes have been a driver in terms of their impacts on the natural environment and in facilitating the cessation of grazing to protect water quality. The potential damage to turbines and pipelines from sedimentation as well as siltation of impoundments was a key factor in hastening the removal of grazing from the NSW Alps (Worboys and Pickering 2002). Over the past decade, the importance of the Alps water, beyond the boundaries of the focal system, has been increasingly recognized and acknowledged (Worboys et al. 2011).

The Australian Alps are a critical water catchment for southeastern Australia. Water production by this focal system is a driver for activities and environmental values in the much larger, coupled Murray-Darling river system. The Alps contributes approximately $25 \%$ of the total flow of this larger system (Lawrence 1992). The Murray-Darling Basin generates A $\$ 15$ billion worth of Australia's agricultural produce annually, including $45 \%$ of Australia's irrigated production, and supports 2.1 million Australians (MDBA 2010). This river system is also the source of domestic water for many inland towns and Adelaide, the capital city of the state of South Australia.

\section{Stage 3: system dynamics}

We previously described key drivers that have affected the system, demonstrating the interactions between these drivers and governance influences. Next, we present a hypothesis concerning the possible future trajectory for the focal system drawing on 
analysis of past, present, and plausible future dynamics. We used the adaptive cycle (Holling and Gunderson 2002) as a heuristic tool for this analysis.

The Alps focal system has moved through several phases of the adaptive cycle over the past 200 years. It has transitioned from an extended conservation phase and then more rapidly cycled through several release and reorganization phases (Table 3). We hypothesize that it is currently in another release phase, with climate change the dominant driver.

The focal system seems to have been largely stable, i.e., in a conservation phase, in terms of the main biodiversity features of the focal system, as described previously, for most of the period since the end of the last Ice Age 15,000 years ago (Galloway 1989, Kershaw and Strickland 1989). Lacking resilience to stock grazing and frequent burning, it was "released" into an unstable phase, i.e., release phase, in the 19th century, characterized by vegetation loss, soil erosion, and hydrologic changes (Table 3). Institutional responses, and in particular dedication of national parks, have averted transformation into a system characterized by broadscale erosion and sediment-laden waters. Scientific research and concerns raised by conservation NGOs were particularly influential in moving the focal system instead into a reorganization phase characterized by cessation of grazing and extensive restoration activities.

The changes wrought by hydroelectric developments have stabilized, and no further system adjustments are expected in response to the shock of the 1950 s to 1970 s wave of hydro development. Recreation and tourism infrastructure has had dramatic local impacts in the recent past on alpine and subalpine ecosystems. There is potential for further impacts if the ski industry in NSW seeks to relocate to higher altitudes in efforts to overcome reduced snow because of climate change.

The drivers that are most likely to determine the future trajectory of alpine and subalpine landscapes are climate change, associated changes to fire regimes and invasive processes, and the intensity and distribution of recreation and tourism use. A positive reinforcement loop, involving a drier and warmer climate that supports an increased potential for fires, threatens to drive the system into a renewed phase of release and reorganization. This will favor expansion of heathlands, movement of snow gums into currently treeless areas, changes in composition and location of grasslands, reduction in the extent and functionality of wetlands, and potential loss of snow patch vegetation. Alpine and subalpine frog species will suffer further population reduction and potentially extinction. The endemic mountain-pygmy possum and local populations of broad-toothed rat are likely to be impacted by seasonal reduction in availability of subnivean habitat and increased predation by foxes.

\section{Stage 4: implications for interventions}

Exploring the implications for interventions requires consideration of (1) the system's likely/possible trajectories, based on our hypothesized adaptive cycle for the Alps focal system, and (2) the extent to which governance interventions can influence the likely trajectories. Our interpretation of the adaptive cycle suggests that movement into a release phase is inevitable given the current state of the focal system and its drivers (Table 3). Given an inability within the SES to mitigate the effects of climate change, a transformed future is the most likely outcome. Thus, forms of governance that can deal with transformation and guide it in directions, as much as is possible, desired by society become the critical concern.

Under a changing climate, invasive processes and the ski industry are two critical drivers of biodiversity conservation in this alpine focal system. A flexible, adaptive approach to managing pest plants and animals is essential, given the uncertainties associated with the extent of projected climate change compounded by uncertainties regarding its effects on wildfire intensity, frequency, and extent and knock-on consequences for invasive processes. Community values and attitudes, irrespective of climate change, are another driver that is pivotal to the future of biodiversity in these publicly "owned" protected landscapes. The complex, multiple interfaces between community values and managing biodiversity within a national park system make consideration of network governance (Rammel et al. 2007, Armitage and Plummer 2010, Newig et al. 2010) a potentially effective response. Network governance can encompass formal structures as well as informal relationships between scientists, government officials, and community organizations, including "shadow networks" of actors who work outside mainstream processes and may help prepare a system for change by exploring alternative approaches to governing (Olsson et al. 2006, Pahl-Wostl et al. 2007). Pathways and barriers toward such an approach are discussed subsequently.

\section{DISCUSSION}

This assessment has provided an integrated resilience assessment of the biodiversity features of the alpine and subalpine regions of the Australian Alps. The assessment began with a description of the governance arrangements of the focal system, especially its domination by national parks as an institution. Biophysical drivers, e.g., invasive processes, and socioeconomic drivers, e.g., community values, tourism, and recreation, overlain by the allpervasive effects of a changing climate, were analyzed alongside governance influences. The drivers and historical analysis using the adaptive cycle heuristic strongly suggests that this system is in a release phase with transformation a real possibility. Based on these analyses, governance within this transforming future will need to be adaptive.

Biodiversity objectives articulated in legislation and management plans for the focal region are founded on maintaining the suite of ecosystems and species that persisted through the long conservation phase that predated European colonization of Australia. Conservation management responses have focused on redressing the impacts that occurred on these ecosystems and species during the release phase and securing the resilience of an altered landscape such that all extant species are conserved. Our analysis suggests that a soon-to-be-experienced transformation associated with a release phase means that such aspirations may be untenable. Reconceptualization of the notion of biodiversity conservation and renegotiation of biodiversity objectives are likely to be required.

The future of this system's biodiversity very much depends on governance arrangements amenable to negotiation of system transformation through deliberative engagement processes. Policy stability to create an environment for long-term investment 
Table 3. Adaptive cycle for the Alps focal region.

\begin{tabular}{|c|c|c|}
\hline $\begin{array}{l}\text { Phase in adaptive } \\
\text { cycle and timing }\end{array}$ & Biodiversity status & Drivers of biodiversity change \\
\hline $\begin{array}{l}\text { 1. Conservation } \\
\text { (K) }-15,000 \text { yrs } \\
\text { before present to } \\
\text { 19th century }\end{array}$ & $\begin{array}{l}\text { Alpine and subalpine } \\
\text { ecosystems largely resilient to } \\
\text { infrequent fires and droughts } \\
\text { for most of } 10,000 \text { years since } \\
\text { last Ice Age }\end{array}$ & Infrequent fires and droughts \\
\hline $\begin{array}{l}\text { 2. Release }(\Omega)- \\
19 \text { th and } 20 \text { th } \\
\text { centuries (to } \\
\text { mid-1940s) }\end{array}$ & $\begin{array}{l}\text { Significant vegetation loss } \\
\text { together with structural and } \\
\text { floristic changes, erosion and } \\
\text { disruption to hydrological } \\
\text { functions }\end{array}$ & $\begin{array}{l}\text { European stock grazing and } \\
\text { associated fires in 19th and } 20 \\
\text { centuries }\end{array}$ \\
\hline & $\begin{array}{l}\text { Significant reduction in wetland } \\
\text { area, with impacts on } \\
\text { dependent species }\end{array}$ & $\begin{array}{l}\text { Ski resorts established with } \\
\text { infrastructure associated with } \\
\text { tourism - roads, buildings }\end{array}$ \\
\hline
\end{tabular}

3. Reorganization Some recovery in vegetation ( $\alpha)-$ mid-1940s to early 21 st century vegetation communities cover and reduction in soil loss approaching a stable but degraded state Populations of species such as mountain pygmy-possum (Burramys parvus) and the corroboree frogs (Pseudophryne) in decline
4. Release $(\Omega)-$ 21 st century (speculative but plausible)
Transformation of vegetation communities and their associated species, with more extensive areas of heathland, further reduction in wetland areas, loss of those communities, and species dependent on long-lasting snow cover, and expansion of snow gum into previously treeless areas
Warming climate, reduced snow depth and duration, more frequent droughts, and extreme rainfall events
Scientific concerns regarding grazing impacts

Early efforts to manage grazing through legislation and leases (largely ineffective)

Largely ad hoc establishment of tourism infrastructure Policy emphasis on resource utilization Reservation of a small part of the NSW Alps for public recreation, preservation of game and preservation of flora Declaration in 1944 of the 522,303 ha Kosciuszko State Park under the management of a board of trustees; Kosciusko State Park Act 1944 (NSW) allowed the Trust to issue private concessions to further develop resorts

Grazing excluded, first from the Government statutory authorities and departments NSW Alps and then Victoria; rehabilitation and restoration of large areas undertaken in NSW

Increased frequency of major fire events

Scientific research into hydrology and impacts of fire and grazing

Cessation of grazing through park creation, research, and NGO lobbying

roads, dams aquectricity schems stations

Expansion of ski resorts and dramatic increase in summer visitation - roads, power, water buildings, tracks

National parks created

Rehabilitation of construction damage from hydro schemes Wide community support for conservation measures, with opposition from traditional user groups

National parks created and government authorities established to manage them - NSW Kosciusko National Park in 1967, ACT Namadgi National Park in 1984, Victorian Alpine National Park in 1989

Park management agencies responsible for fire prevention and suppression

Leases for ski resorts allow for expansion within set boundaries

Environment Protection and Biodiversity Conservation Act 1999 (Cth) enables Australian Government

intervention in decisions affecting MNES, including species, communities, and sites in the Alps Cross-jurisdictional cooperation through the Australian Alps National Parks Cooperative Management Program State of the parks reporting and management effectiveness evaluation

Idealized governance: Deliberative, networked, collaborative governance, informed by management effectiveness evaluations and adaptive management 

Increased presence of weeds and vertebrate pest species
Movement into the high county by some native species previously restricted to lower elevations
Mountain pygmy-possum and corroboree frogs only surviving in artificially maintained populations

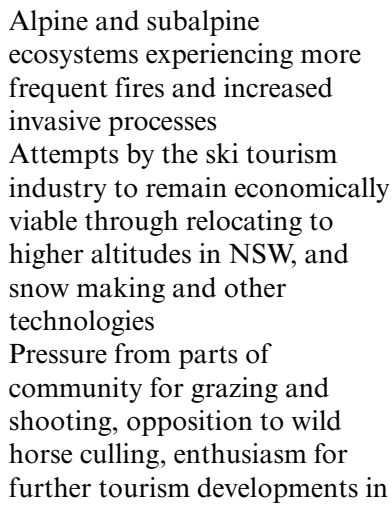

may no longer be tenable in a system facing transformation (Kates et al. 2012). In considering the future of Kruger National Park, Venter et al. (2008) similarly note the growing uncertainty of the environment within which national parks operate. In the case of the Alps focal system, the future challenge is not so much securing system resilience, which is likely to be impossible, but negotiating a way through system transformation in a way valued by society. In this future, the systems of governance for the focal region must support the selection and implementation of strategies that can negotiate system transformation in ways that take account of inevitable loss and attempt to minimize the resulting value deficits, as well as identify and seek to take advantage of new possibilities. For example, should societal resources be put toward translocating species or captive breeding, and, most importantly, who gets to decide and through what types of decision-making processes?

Transformation may require fundamental changes to decisionmaking processes, policy priorities, resource allocations, governance arrangements, and social preferences and norms (Kates et al. 2012). Institutional arrangements able to successfully negotiate transformation, that is, to redefine objectives and establish pathways to a more rather than less desirable future, will probably need to be based on deliberative engagement processes that build trust and shared understandings and draw on structures that connect knowledge with action at appropriate levels (Lebel et al. 2006). This will not be easy, given the historically entrenched divisions between pro-protection and pro-use stakeholders. Engagement processes that first build awareness, followed by acknowledgement of risks and the need to act, have the potential to generate acceptable and implementable adaptation responses (Bardsley and Rogers 2010). Effective deployment of this knowledge demands openness to change and new ideas, as well as a willingness to confront and deal with complex decision contexts (Lockwood et al. 2012).

Resetting the compass for conservation goals for the Australian Alps will require supportive stakeholders and leadership to drive transformational strategies and actions. Both are needed given the uncertainties about future system trajectories, the high costs of transformational action for uncertain benefits, and institutional and behavioral inertia favoring existing governance systems and policies (Kates et al. 2012). In the focal system, governments are pursuing a conservative use-oriented agenda, and key NGOs and ecologists are resisting this push with calls for strong top-down conservation policies, as exemplified in the recent debate concerning reintroduction of stock grazing into national parks by the Victorian government (Garrard and Rumpff 2011). Moving to a network governance model is likely to be resisted by conservation NGOs fearful that this would facilitate further drift of policy priorities away from nature conservation in favor of a more use-oriented regime. The current legislative focus at state and national levels is on threatened species conservation, including iconic species such as the mountain pygmy-possum and corroboree frogs (Pseudophryne corroboree and Pseudophryne pengillyi). Shifting the emphasis to landscapescale ecosystem processes, which would better fit the context of system transformation, is also likely to be resisted by key conservation stakeholders, including some scientists, and the wider public (Moore et al. 2009). It is much easier to "sell" conservation of charismatic fauna species than more technical arguments regarding ecosystem structure and function.

On the other hand, responses to transformation in the focal system have the advantage over other land tenures in that change is much harder to institute in resource systems founded on strong and long-standing property or access rights or traditional practices (Kates et al. 2012). Government management authorities need to consider, for example, whether a multiparty cogovernance model, with well-developed network structures across jurisdictions and between stakeholders, would better fit a transformational context than current arrangements. A move away from the long-standing government agency model for Australian public protected areas toward a more European model along the lines of British national park authorities, for example, is worth investigating. Such structures constitute a network governance model in which a board comprising public conservation and land management agencies, local governments, local communities, and scientists is authorized to plan and make decisions in relation to a specific national park, as with, for example, the Cairngorms National Park Authority (http://cairngorms.co.uk/park-authority/aboutus/).

Two relatively recent innovations may assist such a reform process. The first is the Australian Alps Liaison Committee, an existing institution with a history of fostering deliberation, networking, and knowledge mobilization. This committee also has an emerging track record in engaging with Aboriginal Traditional 
Owners. It thus provides a foundation and opportunities for further extending the cogovernance model. The collaborative and deliberative capacity of this body could be further strengthened by conferring authority on it along the lines of the multiparty cogovernance model indicated previously. The second is the state of the parks reporting and associated adaptive management processes established over the past 5 years in the Alps. It provides a promising base for negotiating system transformation, but the purposes to which these processes are directed will need to be adjusted to suit a transformational rather than a conservation dynamic, as noted previously.

This analysis has importance beyond the focal system we have examined because ecosystem transformations and unprecedented loss of biological diversity driven by a complex of anthropogenic activities, including climate change, are already evident in many parts of the world (Magurran and Dornelas 2010). For example, coastal erosion because of sea-level rise and increased storm surge is projected to cause significant loss of coastal wetlands in Europe over the period 2006 to 2050 (Roebeling et al. 2013). Tidal freshwater wetlands, which support diverse, characteristic vegetation and a rich fauna, are expected to suffer transformation from sea-level rise and reduced river discharge (Barendregt and Swarth 2013). Low-lying islands and deltas are vulnerable to even modest sea-level rise (Kates et al. 2012). Cloern et al. (2011) analyzed likely change in an estuary-watershed system transformation from 2010 to 2099 and concluded that a combination of increasing air and water temperatures, sea-level rise, decreasing precipitation, and changes in freshwater runoff can be expected to transform system biodiversity.

As conditions diverge from those to which native species are adapted, extinction risk for these species will increase and allow those historically not native to the area to become dominant components of the system. Climate change is driving ocean systems toward conditions not seen for millions of years, and irreversible ecological transformation is expected, with impacts including reduced abundance of habitat-forming species and shifting species distributions, with key habitat-forming species such as corals, sea grasses, and mangroves particularly affected (Hoegh-Guldberg and Bruno 2010). In Arctic and temperate alpine regions, ecosystem processes will be altered, with a climatedriven increase in shrub cover in low-Arctic tundra and significant shifts in plant community composition in midlatitude alpine regions (Wookey et al. 2009). In such cases of externally driven system transformation, as with the Australian Alps, an adaptive network-based approach offers a promising governance response.

In making these suggestions for governance reform, we are mindful that opponents of the national parks will attempt to direct reforms such that they better meet their own interests than do the current arrangements. However, a need to reconsider the meaning of biodiversity conservation in a transformational context should not, in our view, undermine the concept of a protected area or the primacy of natural values in driving management objectives. More research, building on the integrated analysis we have provided, is needed to better understand the meaning and purpose of protected areas subject to transformation and how governance can be configured to negotiate this transformation.

\section{CONCLUSION}

Our approach offers a means for identifying critical system elements and dynamics that provides insight into potential resilience or transformation of focal biodiversity features and provides a basis for identifying potentially useful governance responses. The assessment we have provided shows how an adaptive resilience assessment can be successfully applied as a landscape-scale biodiversity planning tool. The resilience workbook approach, as we have modified it, provides a means to consider social and governance elements as integral to system description, to better understand possible future trajectories, and to identify governance and management interventions suitable to move toward desired futures. Our application of this assessment to the Australian Alps demonstrates the potential of this process for establishing an understanding of governance and associated institutions that can frame and guide future actions for valued focal systems and its ready application to explore biodiversity conservation futures in other landscapes.

Responses to this article can be read online at: http://www.ecologyandsociety.org/issues/responses. $\mathrm{php} / 6393$

\section{Acknowledgments:}

This work is an output from the Landscapes and Policy Research Hub. The hub is supported through funding from the Australian government's National Environmental Research Program.

\section{LITERATURE CITED}

Alpine Resorts Co-ordinating Council (ARCC). 2012. Alpine resorts strategic plan 2012. ARCC, Melbourne, Australia. [online] URL: http://www.arcc.vic.gov.au/publications.htm

Armitage, D., and R. Plummer. 2010. Adapting and transforming: governance for navigating change. Pages 287-302 in D. Armitage and R. Plummer, editors. Adaptive capacity and environmental governance. Springer, Heidelberg, Germany. http://dx.doi. org/10.1007/978-3-642-12194-4_14

Australian Bureau of Statistics (ABS). 2013. Community engagement with nature conservation, Australia, 2011-12. ABS, Canberra, Australia. [online] URL: http://www.abs.gov.au/ ausstats/abs@.nsf/mf/4602.0.00.002

Bardsley, D. K., and G. P. Rogers. 2010. Prioritizing engagement for sustainable adaptation to climate change: an example from natural resource management in South Australia. Society \& Natural Resources 24(1):1-17. http://dx.doi.org/10.1080/08941920802287163

Barendregt, A., and C. W. Swarth. 2013. Tidal freshwater wetlands: variation and changes. Estuaries and Coasts 36 (3):445-456. http://dx.doi.org/10.1007/s12237-013-9626-Z

Bhend, J., J. Bathols, and K. Hennessy. 2012. Climate change impacts on snow in Victoria. CSIRO Marine and Atmospheric Research, Aspendale, Australia. 
Bowman, D. M. J. S., J. Balch, P. Artaxo, W. J. Bond, M. A. Cochrane, C. M. D’Antonio, R. DeFries, F. H. Johnston, J. E. Keeley, and M. A. Krawchuk, C. A. Kull, M. Mack, M. A. Mortiz, S. Pyne, C. I. Roos, A. C. Scott, N. S. Sodhi, and T. W. Swetnam. 2011. The human dimension of fire regimes on Earth. Journal of Biogeography 38(12):2223-2236. http://dx.doi.org/10.1111/ j.1365-2699.2011.02595.X

Butchart, S. H. M., M. Walpole, B. Collen, A. van Strien, J. P. W. Scharlemann, R. E. A. Almond, J. E. M. Baillie, B. Bomhard, C. Brown, J. Bruno, K. E. Carpenter, G. M. Carr, J. Chanson, A. M. Chenery, J. Csirke, N. C. Davidson, F. Dentener, M. Foster, A. Galli, J. N. Galloway, P. Genovesi, R. D. Gregory, M. Hockings, V. Kapos, J.-F. Lamarque, F. Leverington, J. Loh, M. A. McGeoch, L. McRae, A. Minasyan, M. Hernández Morcillo, T. E. E. Oldfield, D. Pauly, S. Quader, C. Revenga, J. R. Sauer, B. Skolnik, D. Spear, D. Stanwell-Smith, S. N. Stuart, A. Symes, M. Tierney, T. D. Tyrrell, J.-C. Vié, and R. Watson. 2010. Global biodiversity: indicators of recent declines. Science 328 (5982):1164-1168. http://dx.doi.org/10.1126/science.1187512

Camac, J. S., R. J. Williams, C.-H. Wahren, W. K. Morris, and J. W. Morgan. 2013. Post-fire regeneration in alpine heathland: does fire severity matter? Austral Ecology 38(2):199-207. http://dx.doi. org/10.1111/j.1442-9993.2012.02392.X

Chapin, F. S., III, E. S. Zavaleta, V. T. Eviner, R. L. Naylor, P. M. Vitousek, H. L. Reynolds, D. U. Hooper, S. Lavorel, O. E. Sala, S. E. Hobbie, M. C. Mack, and S. Díaz. 2000. Consequences of changing biodiversity. Nature 405(6783):234-242. http://dx.doi. org/10.1038/35012241

Cloern, J. E., N. Knowles, L. R. Brown, D. Cayan, M. D. Dettinger, T. L. Morgan, D. H. Schoellhamer, M. T. Stacey, M. van der Wegen, R. W. Wagner, and A. D. Jassby. 2011. Projected evolution of California's San Francisco Bay-Delta-River system in a century of climate change. PLOS ONE 6(9):e24465. http:// dx.doi.org/10.1371/journal.pone.0024465

Crabb, P., and S. Dovers. 2007. Managing natural resources across jurisdictions: lessons from the Australian Alps. Australasian Journal of Environmental Management 14(4):210-219. http://dx. doi.org/10.1080/14486563.2007.10648719

Dawson, M. 2009. Aerial survey of feral horses in the Australian Alps. Report prepared for the Australian Alps Liaison Committee, Canberra, Australia. [online] URL: http://www. australianalps.environment.gov.au/publications/research-reports/ feral-horses-aerial-survey.html

Devinney, T., P. Auger, and R. DeSailly. 2012. What matters to Australians: our social, political and economic values. University of Technology, Sydney, Sydney, Australia; University of Melbourne, Melbourne, Australia. [online] URL: http://hdl. handle.net/10453/21789

Du Toit, J. T., K. H. Rogers, and H. C. Biggs. 2003. The Kruger experience: ecology, and management of savannah heterogeneity. Island, Washington, D.C., USA.

Federal Court of Australia. 2013. Secretary to the Department of Sustainability and Environment (Vic) v Minister for Sustainability, Environment, Water, Population and Communities (Cth) [2013]
FCA 1. Federal Court of Australia, Melbourne, Australia. [online] URL: http://www.judgments.fedcourt.gov.au/judgments/ Judgments/fca/single/2013/2013fca0001

Flood, J. 1992. Aboriginal cultural heritage of the Australian Alps: an overview. Pages 83-87 in B. Scougall, editor. Cultural heritage of the Australian Alps. Australian Alps Liaison Committee, Canberra, Australia.

Folke, C., S. R. Carpenter, B. Walker, M. Scheffer, T. Chapin, and J. Rockström. 2010. Resilience thinking: integrating resilience, adaptability and transformability. Ecology and Society 15(4): 20. [online] URL: http://www.ecologyandsociety.org/vol15/iss4/ $\underline{\operatorname{art} 20 /}$

Galloway, R. W. 1989. Glacial and periglacial features of the Australian Alps. Pages 55-67 in R. Good, editor. The scientific significance of the Australian Alps. Australian Alps National Parks Liaison Committee, Canberra, Australia.

Garrard, G., and L. Rumpff. 2011. Science the loser in Victoria's alpine grazing trial. Conversation [online] URL: http:// theconversation.com/science-the-loser-in-victorias-alpine-grazingtrial-3

Geneletti, D., and I. van Duren. 2008. Protected area zoning for conservation and use: a combination of spatial multicriteria and multiobjective evaluation. Landscape and Urban Planning 85 (2):97-110. http://dx.doi.org/10.1016/j.landurbplan.2007.10.004

Genter, S., S. A. Moore, and J. Bailey. 2008. Developing and testing a policy environmental assessment checklist for biodiversity conservation. Impact Assessment and Project Appraisal 26(3):189-200. http://dx.doi.org/10.3152/146155108X333299

Gibbons, P., L. van Bommel, A. M. Gill, G. J. Cary, D. A. Driscoll, R. A. Bradstock, E. Knight, M. A. Moritz, S. L. Stephens, and D. B. Lindenmayer. 2012. Land management practices associated with house loss in wildfires. $P \operatorname{LOS} O N E 7(1): \mathrm{e} 29212$. http://dx. doi.org/10.1371\%2Fjournal.pone.0029212

Gillson, L., T. P. Dawson, S. Jack, and M. A. McGeoch. 2013. Accommodating climate change contingencies in conservation strategy. Trends in Ecology \& Evolution 28(3):135-142. http://dx. doi.org/10.1016/j.tree.2012.10.008

Good, R. B. 1992. Kosciusko heritage. NSW National Parks \& Wildlife Service, Sydney, Australia.

Good, R. B. 2006. The Australian Alps rehabilitation manual. Australian Alps Liaison Committee, Canberra, Australia.

Green, K., and C. M. Pickering. 2002. A scenario for mammal and bird diversity in the Australian Snowy Mountains in relation to climate change. Pages 241-249 in C. Körner and E. M. Spehn, editors. Mountain biodiversity: a global assessment. Parthenon, London, United Kingdom.

Green, K., and G. Sanecki. 2006. Immediate and short-term responses of bird and mammal assemblages to a subalpine wildfire in the Snowy Mountains, Australia. Austral Ecology 31 (6):673-681. http://dx.doi.org/10.1111/j.1442-9993.2006.01629.x

Gregory, R., G. Long, M. Colligan, J. G. Geiger, and M. Laser. 2012. When experts disagree (and better science won't help much): 
using structured deliberations to support endangered species recovery planning. Journal of Environmental Management 105:30-43. http://dx.doi.org/10.1016/j.jenvman.2012.03.001

Growcock, A. J., E. F. Sutherland, and P. T. Stathis. 2009. Challenges and experiences in implementing a management effectiveness evaluation program in a protected area system. Australasian Journal of Environmental Management 16 (4):218-226. http://dx.doi.org/10.1080/14486563.2009.9725237

Hatt, K. 2013. Social attractors: a proposal to enhance "resilience thinking" about the social. Society \& Natural Resources 26 (1):30-43. http://dx.doi.org/10.1080/08941920.2012.695859

Haward, M., J. Davidson, M. Lockwood, M. Hockings, L. Kriwoken, and R. Allchin. 2013. Climate change, scenarios and marine biodiversity conservation. Marine Policy 38:438-446. http://dx.doi.org/10.1016/j.marpol.2012.07.004

Hawke, A. 2009. The Australian Environment Act: report of the independent review of the Environment Protection and Biodiversity Conservation Act 1999. Department of the Environment, Water, Heritage and the Arts, Canberra, Australia.

Hennessy, K. J., P. H. Whetton, K. Walsh, I. N. Smith, J. M. Bathols, M. Hutchinson, and J. Sharples. 2008. Climate change effects on snow conditions in mainland Australia and adaptation at ski resorts through snowmaking. Climate Research 35 (3):255-270. http://dx.doi.org/10.3354/cr00706

Hockings, M., C. N. Cook, R. W. Carter, and R. James. 2009. Accountability, reporting, or management improvement? Development of a State of the Parks assessment system in New South Wales, Australia. Environmental Management 43 (6):1013-1025. http://dx.doi.org/10.1007/s00267-009-9277-9

Hodgson, G. M. 2006. What are institutions? Journal of Economic Issues 40:1-25.

Hoegh-Guldberg, O., and J. F. Bruno. 2010. The impact of climate change on the world's marine ecosystems. Science 328 (5985):1523-1528. http://dx.doi.org/10.1126/science.1189930

Holling, C. S., and L. H. Gunderson. 2002. Resilience and adaptive cycles. Pages 25-62 in L. H. Gunderson and C. S. Holling, editors. Panarchy synopsis: understanding transformations in human and natural systems. Island, Washington, D.C., USA.

Hope, G., R. Nanson, and I. Flett. 2009. The peat-forming mires of the Australian Capital Territory. ACT Department of Territory and Municipal Services, Canberra, Australia.

Hornborg, A. 2009. Zero-sum world: challenges in conceptualizing environmental load displacement and ecologically unequal exchange in the world-system. International Journal of Comparative Sociology 50(3-4):237-262. http://dx.doi. org/10.1177/0020715209105141

Hunter, D., W. Osborne, M. Smith, and K. McDougall. 2009. Breeding habitat use and the future management of the critically endangered Southern Corroboree Frog. Ecological Management \& Restoration 10:S103-S109. http://dx.doi.org/10.1111/ j.1442-8903.2009.00461.X

Jacobson, C., R. W. Carter, and M. Hockings. 2008. The status of protected area management evaluation in Australia and implications for its future. Australasian Journal of Environmental Management 15(4):202-210. http://dx.doi.org/10.1080/14486563.2008 .9725204

Kamminga, J. 1992. Aboriginal settlement and prehistory in the Snowy Mountains. Pages 101-124 in B. Scougall, editor. Cultural heritage of the Australian Alps. Australian Alps Liaison Committee, Canberra, Australia.

Kates, R. W., W. R. Travis, and T. J. Wilbanks. 2012. Transformational adaptation when incremental adaptations to climate change are insufficient. Proceedings of the National Academy of Sciences of the United States of America 109 (19):7156-7161. http://dx.doi.org/10.1073/pnas.1115521109

Kershaw, A. P., and K. M. Strickland. 1989. The development of alpine vegetation on the Australian mainland. Pages 113-126 in R. Good, editor. The scientific significance of the Australian Alps. Australian Alps National Parks Liaison Committee, Canberra, Australia.

Lawrence, R. E. 1992. Use and abuse of water in the Victorian Alps. Pages 295-308 in B. Scougall, editor. Cultural heritage of the Australian Alps. Australian Alps Liaison Committee, Canberra.

Lebel, L., J. M. Anderies, B. Campbell, C. Folke, S. HatfieldDodds, T. P. Hughes, and J. Wilson. 2006. Governance and the capacity to manage resilience in regional social-ecological systems. Ecology and Society 11(1): 19. [online] URL: http://www. ecologyandsociety.org/vol11/iss1/art19/

Lockwood, M., J. Davidson, M. Hockings, M. Haward, and L. Kriwoken. 2012. Marine biodiversity conservation governance and management: regime requirements for global environmental change. Ocean \& Coastal Management 69:160-172. http://dx.doi. org/10.1016/j.ocecoaman.2012.07.015

Macdonald, T. 2009. Sphagnum bog mapping and recovery plan. ACT Climate Change Strategy Action Plan 2007-2011, Action 35 Project Technical Report 20, Territory and Municipal Services ACT, Canberra, Australia.

Magurran, A. E., and M. Dornelas. 2010. Biological diversity in a changing world. Philosophical Transactions of the Royal Society B: Biological Sciences 365(1558):3593-3597. http://dx.doi. org/10.1098/rstb.2010.0296

McDougall, K. L. 2003. Aerial photographic interpretation of vegetation changes on the Bogong High Plains, Victoria, between 1936 and 1980. Australian Journal of Botany 51(3):251-256. http:// dx.doi.org/10.1071/BT02079

McDougall, K. L. 2007. Grazing and fire in two subalpine peatlands. Australian Journal of Botany 55(1):42-47. http://dx.doi. org/10.1071/BT06096

McDougall, K. L., J. W. Morgan, N. G. Walsh, and R. J. Williams. 2005. Plant invasions in treeless vegetation of the Australian Alps. Perspectives in Plant Ecology, Evolution and Systematics 7 (3):159-171. http://dx.doi.org/10.1016/j.ppees.2005.09.001

McDougall, K. L., and N. G. Walsh. 2007. Treeless vegetation of the Australian Alps. Cunninghamia 10(1):1-57.

McGinnis, M. D. 2011. An introduction to IAD and the language of the Ostrom workshop: a simple guide to a complex framework. 
Policy Studies Journal 39:169-183. http://dx.doi.org/10.1111/ j.1541-0072.2010.00401.x

McGregor, A., B. Coffey, C. Deutsch, G. Wescott, and J. Robinson. 2011. What are the policy priorities for sustaining ecological processes? A case study from Victoria, Australia. Ecological Management \& Restoration 12(3):194-199. http://dx. doi.org/10.1111/j.1442-8903.2011.00598.x

Millennium Ecosystems Assessment. 2005. Ecosystems and human well-being: synthesis. Island, Washington, D.C., USA.

Moore, S. A., T. J. Wallington, R. J. Hobbs, P. R. Ehrlich, C. S. Holling, S. Levin, D. Lindenmayer, C. Pahl-Wostl, H. Possingham, and M. G. Turner. 2009. Diversity in current ecological thinking: implications for environmental management. Environmental Management 43(1):17-27. http://dx.doi.org/10.1007/ $\underline{\text { s00267-008-9187-2 }}$

Morrison, C., and C. Pickering. 2012. Climate change adaptation in the Australian Alps: impacts, strategies, limits and management. National Climate Change Adaptation Research Facility, Gold Coast, Australia. [online] URL: http://www.nccarf.edu.au/sites/ default/files/attached files publications/Morrison_2012 LimitsAustralian Alps.pdf

Murray-Darling Basin Authority (MDBA). 2010. Guide to the proposed basin plan: overview. Volume 1. MDBA, Canberra, Australia.

National Institute of Economic and Industry Research (NIEIR). 2012. The economic significance of the Australian alpine resorts winter season 2011. NIEIR, Melbourne, Australia. [online] URL: http://www.arcc.vic.gov.au/aarp.htm

Newig, J., D. Günther, and C. Pahl-Wostl. 2010. Synapses in the network: learning in governance networks in the context of environmental management. Ecology and Society 15(4): 24. [online] URL: http://www.ecologyandsociety.org/vol15/iss4/ $\underline{\operatorname{art} 24 /}$

Olsson, P., Ö. Bodin, and C. Folke. 2010. Building transformative capacity for ecosystem stewardship in social-ecological systems. Pages 263-286 in D. Armitage and R. Plummer, editors. Adaptive capacity and environmental governance. Springer, Heidelberg, Germany. http://dx.doi.org/10.1007/978-3-642-12194-4_13

Olsson, P., L. H. Gunderson, S. R. Carpenter, P. Ryan, L. Lebel, C. Folke, and C. S. Holling. 2006. Shooting the rapids: navigating transitions to adaptive governance of social-ecological systems. Ecology and Society 11(1): 18. [online] URL: http://www. ecologyandsociety.org/vol11/iss1/art18/

Ostrom, E., and M. Cox. 2010. Moving beyond panaceas: a multitiered diagnostic approach for social-ecological analysis. Environmental Conservation 37(4):451-463. http://dx.doi.org/10.1017/ S0376892910000834

Paavola, J. 2007. Institutions and environmental governance: a reconceptualization. Ecological Economics 63(1):93-103. http:// dx.doi.org/10.1016/j.ecolecon.2006.09.026

Paavola, J., A. Gouldson, and T. Kluvánková-Oravská. 2009. Interplay of actors, scales, frameworks and regimes in the governance of biodiversity. Environmental Policy and Governance 19:148-158. http://dx.doi.org/10.1002/eet.505
Pahl-Wostl C., M. Craps, A. Dewulf, E. Mostert, D. Tabara D, and T. Taillieu. 2007. Social learning and water resources management. Ecology and Society 12(2): 5. [online] URL: http:// www.ecologyandsociety.org/vol12/iss2/art5/

Pickering, C. 2011. Changes in demand for tourism with climate change: a case study of visitation patterns to six ski resorts in Australia. Journal of Sustainable Tourism 19(6):767-781. http:// dx.doi.org/10.1080/09669582.2010.544741

Pickering, C., and T. Armstrong. 2000. Climate change and the plant communities of the Kosciuszko alpine zone in the Australian Alps. CRC for Sustainable Tourism, Gold Coast, Australia.

Pickering, C., R. Good, and K. Green. 2004. Potential effects of global warming on the biota of the Australian Alps. Australian Greenhouse Office, Canberra, Australia.

Pickering, C., and W. Hill. 2007. Roadside weeds of the Snowy Mountains, Australia. Mountain Research and Development 27 (4):359-367. http://dx.doi.org/10.1659/mrd.0805

Rammel, C., S. Stagl, and H. Wilfing. 2007. Managing complex adaptive systems - a co-evolutionary perspective on natural resource management. Ecological Economics 63(1):9-21. http:// dx.doi.org/10.1016/j.ecolecon.2006.12.014

Rands, M. R. W., W. M. Adams, L. Bennun, S. H. M. Butchart, A. Clements, D. Coomes, A. Entwistle, I. Hodge, V. Kapos, J. P. W. Scharlemann, W. J. Sutherland, and B. Vira. 2010. Biodiversity conservation: challenges beyond 2010. Science 329(5997):1298-1303. http://dx.doi.org/10.1126/science.1189138

Resilience Alliance. 2007a. Assessing and managing resilience in social-ecological systems: a practitioners workbook. Volume 1, version 1.0. Resilience Alliance, Stockholm, Sweden.

Resilience Alliance. 2007b. Assessing resilience in social-ecological systems: a workbook for scientists. Resilience Alliance, Stockholm, Sweden. [online] URL: http://www.resalliance.org/ index.php/resilience assessment

Resilience Alliance. 2010. Assessing resilience in social-ecological systems: workbook for practitioners (revised version 2.0) Resilience Alliance, Stockholm, Sweden. [online] URL: http:// www.resalliance.org/index.php/resilience assessment

Roebeling, P. C., L. Costa, L. Magalhães-Filho, and V. Tekken. 2013. Ecosystem service value losses from coastal erosion in Europe: historical trends and future projections. Journal of Coastal Conservation 17(3):389-395. http://dx.doi.org/10.1007/ s11852-013-0235-6

Secretariat of the Convention on Biological Diversity (SCBD). 2010. Strategic plan for biodiversity 2011-2020 and the Aichi targets. SCBD, Montreal, Quebec, Canada.

Spehn, E. M., B. Messerli, and C. Körner. 2002. A global assessment of mountain biodiversity: synthesis. Pages 325-330 in C. Körner and E. M. Spehn, editors. Mountain biodiversity: a global assessment. Parthenon, London, United Kingdom.

Strickland-Munro, J. K., H. E. Allison, and S. A. Moore. 2010. Using resilience concepts to investigate the impacts of protected area tourism on communities. Annals of Tourism Research 37 (2):499-519. http://dx.doi.org/10.1016/j.annals.2009.11.001 
Venter, F. J., R. J. Naiman, H. C. Biggs, and D. J. Pienaar. 2008. The evolution of conservation management philosophy: science, environmental change and social adjustments in Kruger National Park. Ecosystems 11:173-192. http://dx.doi.org/10.1007/s10021-007-9116$\underline{\mathrm{x}}$

Wahren, C.-H., J. S. Camac, F. C. Jarrad, R. J. Williams, W. A. Papst, and A. A. Hoffmann. 2013. Experimental warming and long-term vegetation dynamics in an alpine heathland. Australian Journal of Botany 61(1):36-51. http://dx.doi.org/10.1071/ $\underline{\text { BT12234 }}$

Wahren, C., W. Papst, and R. J. Williams. 1994. Long-term vegetation change in relation to cattle grazing in sub-alpine grassland and heathland on the Bogong High-Plains: an analysis of vegetation records from 1945 to 1994. Australian Journal of Botany 42(6):607-639. http://dx.doi.org/10.1071/BT9940607

Walsh, N. G., and K. L. McDougall. 2004. Progress in the recovery of the flora of treeless subalpine vegetation in Kosciuszko National Park after the 2003 fires. Cunninghamia 8(4):439-452.

Weiler, B., S. A. Moore, and B. D. Moyle. 2013. Building and sustaining support for national parks in the 21st century: why and how to save the national park experience from extinction. Journal of Park and Recreation Administration 31(2). [online] URL: http:// js.sagamorepub.com/jpra/article/view/3889

Williams, R. J., and D. H. Ashton. 1987. Effects of disturbance and grazing by cattle on the dynamics of heathland and grassland communities on the Bogong High Plains, Victoria. Australian Journal of Botany 35(4):413-431. http://dx.doi.org/10.1071/ $\underline{\text { BT9870413 }}$

Williams, N. S. G., and K. D. Holland. 2007. The ecology and invasion history of hawkweeds (Hieracium species) in Australia. Plant Protection Quarterly 22(2):76-80.

Williams, J. W., S. T. Jackson, and J. E. Kutzbach. 2007. Projected distributions of novel and disappearing climates by 2100 AD. Proceedings of the National Academy of Sciences of the United States of America 104(14):5738-5742. http://dx.doi.org/10.1073/ pnas.0606292104

Williams, R. J., C.-H. Wahren, R. A. Bradstock, and W. J. Müller. 2006. Does alpine grazing reduce blazing? A landscape test of a widely-held hypothesis. Austral Ecology 31(8):925-936. http://dx. doi.org/10.1111/j.1442-9993.2006.01655.x

Williams, R. J., C.-H. Wahren, A. D. Tolsma, G. M. Sanecki, W. A. Papst, B. A. Myers, K. L. McDougall, D. A. Heinze, and K. Green. 2008. Large fires in Australian alpine landscapes: their part in the historical fire regime and their impacts on alpine biodiversity. International Journal of Wildland Fire 17(6):793-808. http://dx.doi.org/10.1071/WF07154

Wimbush, D., and A. Costin. 1983. Trends in drainage characteristics in the subalpine zone at Kosciusko. Pages 143-154 in R. W. Purdie and I. R. Noble, editors. Mountain ecology in the Australian region: proceedings of the Ecological Society of Australia Symposium, Volume 12 (Canberra, 8-9 May 1982). Surrey Beatty and Sons, Sydney, Australia.

Winter, C., and M. Lockwood. 2004. The natural area value scale: a new instrument for measuring natural area values. Australasian
Journal of Environmental Management 11(1):11-20. http://dx.doi. org/10.1080/14486563.2004.10648594

Wookey, P. A., R. Aerts, R. D. Bardgett, F. Baptist, K. A. Bråthan, J. H. C. Cornelissen, L. Gough, I. P. Hartley, D. W. Hopkins, S. Lavorerl, and G. R. Shaver. 2009. Ecosystem feedbacks and cascade processes: understanding their role in the responses of Arctic and alpine ecosystems to environmental change. Global Change Biology 15(5):1153-1172. http://dx.doi.org/10.1111/ j.1365-2486.2008.01801.x

Worboys, G. L., W. L. Francis, and M. Lockwood, editors. 2010. Connectivity conservation management: a global guide. Earthscan, London, United Kingdom.

Worboys, G. L., R. B. Good, and A. Spate. 2011. Caring for our Australian Alps catchments. Australian Alps Liaison Committee, Department of Climate Change and Energy Efficiency, Canberra, Australia.

Worboys, G. L., and C. M. Pickering. 2002. Managing the Kosciuszko alpine area: conservation milestones and future challenges. CRC for Sustainable Tourism, Gold Coast, Australia.

Wyborn, C. 2011. Landscape scale ecological connectivity: Australian survey and rehearsals. Pacific Conservation Biology 17 (2):121-131.

Wyborn, C., and R. P. Bixler. 2013. Collaboration and nested environmental governance: scale dependency, scale framing, and cross-scale interactions in collaborative conservation. Journal of Environmental Management 123:58-67. http://dx.doi.org/10.1016/ j.jenvman.2013.03.014

Zylstra, P. 2006. Fire history of the Australian Alps, prehistory to 2003. Australian Alps Liaison Committee, Department of the Environment and Heritage, Canberra, Australia. 